\title{
Global Economy and Human Health
}

Chia Ching $\mathrm{C}^{1^{*}}$ and Ming Chiu $\mathrm{I}^{2}$

${ }^{1}$ Department of Epidemiology and Community Health, School of Health Sciences and Practice, New York Medical College, New York, USA

${ }^{2}$ Department of Economics, Rutgers University, USA

"Corresponding author: Chia-Ching Chen, Department of Epidemiology and Community Health, School of Health Sciences and Practice, New York Medical College, New York, USA, Tel:+ 9145943379; E-mail: ChiaChing_Chen@nymc.edu

Rec date: November 27, 2017; Acc date: November 28, 2017; Pub date: November 28, 2017

Copyright: (c) 2017 Chia CC, et al. This is an open-access article distributed under the terms of the Creative Commons Attribution License, which permits unrestricted use, distribution, and reproduction in any medium, provided the original author and source are credited.

Citation: Ching CC, Ming Cl (2017) Global Economy and Human Health. J Glob Econ 5: e111. doi: 10.4172/2375-4389.1000e111

\section{Theme of Global Economy and Human Health}

The Free trade effort made by a number of agreements and international organizations has significantly reduced trade barriers among countries. The interrelationship and interconnectedness between countries are getting increasingly close with international trade and the rapid spread of the Internet. Goods, services, financial capital, information technology are flowing between countries without borders. People can have all kinds of knowledge they search for at their fingertips. These flourishing developments enable countries gain from their comparative advantages, improve their production effectiveness, and therefore achieve high and sustainable economic growth. While the economic growth helps lift poor and underdeveloped economies, there are consequences from this process of fast globalization, both socially and environmentally. They affect the structure of the economy, environment, human health, and human well-beings in a large scale.

Since the beginning of the twentieth century, capitalism has been introduced from the developed economies to the rest of the world. While the concept of capitalism and free market enhance competition and generate new wealth, the income gap has been increasing globally, and strongly associated with health disparity observed everywhere; empirical evidence indicates high income inequality, using Gini coefficient, is associated with high infant mortality rate, deteriorating mental health and shorter life expectancy. Climate change and global warning are no longer slogans, but urgent tasks to solve. Strange weather patterns and their impact on agricultural goods affect human survival. New oil well drilling technology increases the production of oil and lowers the global oil prices. It helps reduce production cost significantly, while the cost of air and water pollution in terms of human health and the related health care spending is tremendous. To name a few: the higher frequency of earth quakes, hurricanes, various natural disasters have occurred in both east and west hemispheres; the outbreak of Severe acute respiratory syndrome (SARS) from Asian countries in 2002, and the most recent large-scale West Nile virus occurred in the U.S. in 2012 that caused global panic and bans on international traveling. In China, industrial pollution with economic development/growth has made millions of people without clean air and safe water; it has made cancer China's leading cause of death. Additionally, while profit-oriented international business firms continue searching for new markets, the developing countries and their public health officials are facing different imported threats such as obesity, diabetes and heart disease possibly from the introduction of the western-style fast food. Studies show that, over the past three decades, the obesity rate has increased significantly in many countries in the Middle East and North Africa countries. This obesity phenomenon is not only regional but a pandemic risk.

\section{Impact of Globalization}

In this special edition, we invite all scholars to examine the impact of globalization on human health. Any topic that involves income inequality, health disparities or relevant issues are welcome. Papers are invited to address one or more of the following:

Income and Health Disparity.

Environment and Health Risk Assessment.

Environment and Public Health Policy.

International Trade and Human Health.

Human Health and Public Health Policy. 